\title{
The Historical Process of Development of Engineering Sciences as a School Discipline in France
}

\author{
Hamon Christian*, Lebeaume Joël \\ Education Research Laboratory, Paris Descartes University, France
}

Copyright $(2016$ by authors, all rights reserved. Authors agree that this article remains permanently open access under the terms of the Creative Commons Attribution License 4.0 International License

\begin{abstract}
This paper describes the historical process of development of engineering sciences as a school discipline and as an academic subject. It aims to understand the evolution of contents and their structuration, mainly, of the industrial technology for men and of the home economics for women, from the Liberation to today. It contributes to analyze the history of technology education in the basic school and its positioning in the curriculum. This historical and didactic research focuses on the prescribed curriculum, analyzing official texts about contents (practical tasks, functional analysis, graphic tools, modelling...), the training and the certification of teachers, equipment and administrative organization. It identifies the concordances between the emergence of engineering sciences within the university, their development within the tertiary and secondary schools and the development of technology education within the basic education. This contextualized sociological and political history reveals the movement of the deprofessionalization and the despecialization of the current courses, the opportunities to take into account of the sustainable development, the relegation of producing, the priorities for scientific approaches, the integration of mechanics, electronics, automatics, energetics and numerical tools.
\end{abstract}

Keywords Curriculum, Disciplinarization, Engineering Sciences, Technical Teaching, Technology Education

\section{Introduction}

This paper [1] describes the disciplinarization-process [2] of a component of French technical teaching, i.e., the historical process of the development of engineering sciences as a school discipline and as an academic subject. It aims to understand the evolution of contents and their structuration, mainly, of the industrial technology for men, and of home economics for women, from the Liberation to today. It contributes to analyze the history of technology education in the basic school and its positioning in the curriculum [3]. It also enlightens the specificity of the French school organization characterized by its three ways to get high school diploma.

\section{Methods}

This historical and didactic analysis focuses on the prescribed curriculum and merges two researches which use two similar investigation tools:

(i) the first one concerns the history of manual work within primary school and the history of technology education within junior high school. In order to identify the various forms of manual work and technology education along the $20^{\text {th }}$ century, J. Lebeaume [4] proposes a tool to characterize the predominant prototypical situations encountered in teaching-learning. A prototypical situation is characterized by the tasks, their significance, and their orientation: What exactly are the pupils doing? And why are they doing it? How do these tasks refer to actual practices? Figure 1 illustrates this coherence in the reciprocal relationships between the three components of this school matter: purposes, references, and tasks.

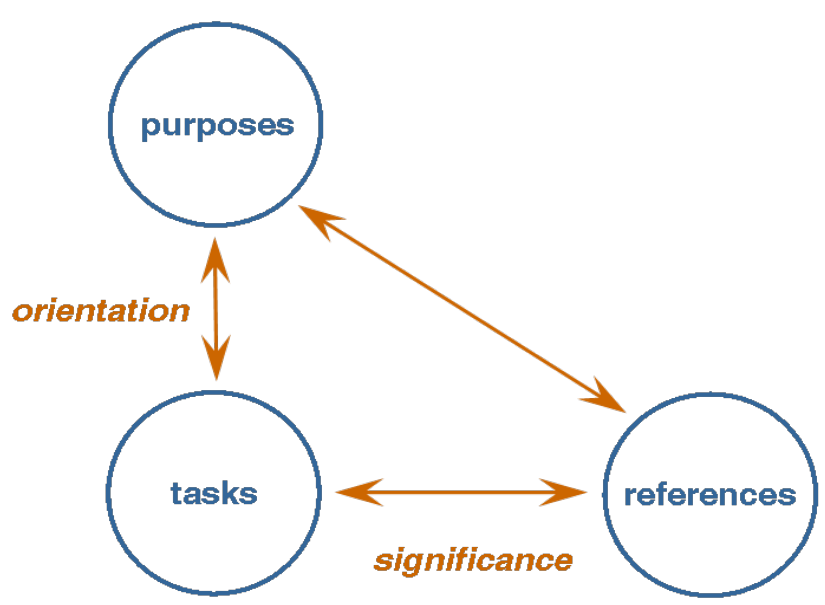

Figure 1. Representation of prototypical teaching-learning situations: Method. 
The diagram in Figure 1 depicts the coherent structure present in each form of the discipline and represents a method, which is to be defined as the special methodology of the discipline. It is necessary to distinguish between the pedagogical and didactic meanings of the methods observed. This distinction does not pertain to the relationships between purposes and means, as do the active methods (pedagogical meaning). According to the didactics perspective, the term method draws attention to subject content. It indicates the special methodology behind a school subject, with its features and its specific knowledge. It has been used in the past for music learning, for example, to distinguish between the marked method and the numbered method.

(ii) The survey of C. Hamon about technical education within high school [5] is supported by the investigation tool (Figure 2). It allows to highlight the consistency of a curriculum by focusing on its missions, its administrative and pedagogical organization (school, training and teachers' certification) and its contents (practical tasks, functional analysis, graphics tools, modelling...). This tool also permits to analyze how this curriculum, always is legitimate, feasible and efficient in order to exist and to survive.

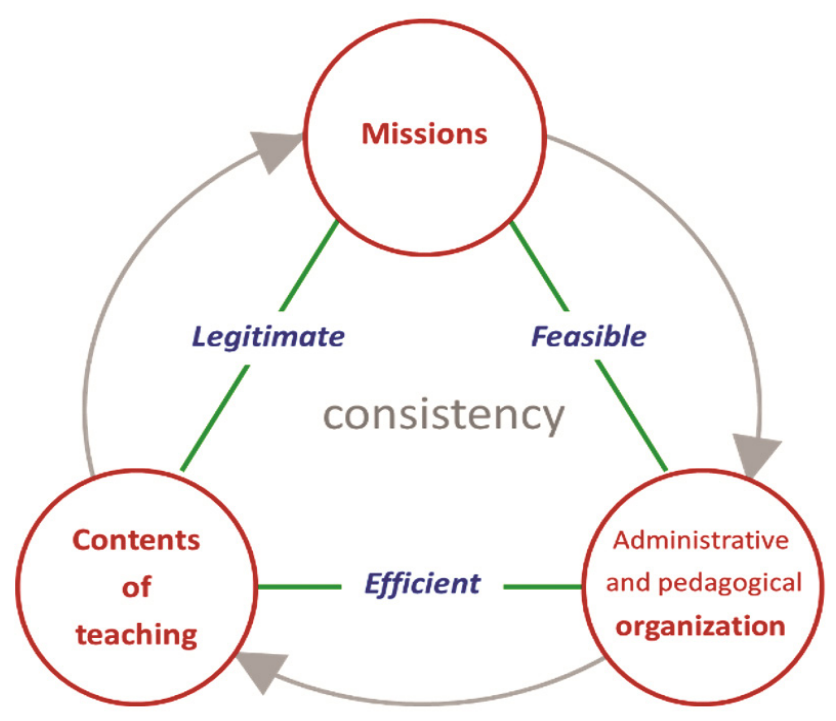

Figure 2. Investigation tool of curriculum

The two tools are complementary. The "prototypical situations" encountered in teaching-learning define the didactic foundations of school-subjects such as the notion of "paradigm" developed in this paper.

The two researches use a similar data collection, constituted by official texts, school syllabus, pedagogical and professional papers, and interviews of teachers and inspectors.

\section{Results}

Taking into account the sociological and political context this history reveals the disciplinarization-process divided in six main periods.

\subsection{After the Liberation: A New Structure for Technical School and Diploma}

Following the Second World War, such as the others countries, France has to be rebuilt. Technical education is specially requested in order to develop the workforce and to help the families deeply affected by war, by providing food, health and housing. Several administrative and pedagogical reforms affect the technical education in order to include it in the school system. Their middle and high vocational schools are restructured in order to train the workmen, the technicians and the future engineers or teachers. The three respective diplomas are the "vocational ability certificate" (instituted in 1920), the "industrial training certificate" (instituted in 1893) and the "technical high school diploma" (Baccalauréat technique: just created in 1946). Pupils respectively are being coached for the exam in specific technical schools: "apprentice center" (vocational middle school created in 1944), "local vocational school" (vocational middle school created in 1893) and the most prestigious "national vocational school" (national vocational high school created in 1903).

For all of these degrees, the boys learn three technical school-subjects: technology of mechanical manufacturing, manual work on mechanical-tools and technical drawing. The technical teaching for young boys is organized around the elements of the "machines paradigm", while the young girls are trained for the "vocational ability certificate" of home economics. They learn cutting clothes and sewing, and applied sciences for housework [6]. The syllabus are divided in two parts: (i) practical teaching is implemented by teachers who are senior workmen recruited by the management of the technical education or directly employed by the school establishments; and (ii) theoretical teaching with teachers who are recruited by national competitive examinations, trained and certified for teaching.

In 1952, a new "vocational technician diploma" is created in order to increase vocational qualifications and to resorb the penury of technicians (Matrix 1). In the same period arts and crafts are implemented within general junior high school. The aims of these new "educative manual works" mainly are to reveal the interests and aptitudes of the teenagers for manual jobs and to discover their perseverance and their sense of teams work. Pupils produce useful and fun artefacts: wood and iron for boys, sewing, dress making and cooking for girls. Their teachers have a specific certification: manual work for the men or home economics for the women.

But this specific hierarchic and compartmentalized organization of technical education, patiently built by their defenders, does not resist to the requirements of the democratization of the education. 


\begin{tabular}{|c|c|c|c|c|c|}
\hline Organization & \multicolumn{4}{|c|}{ Technical teaching } & $\begin{array}{l}\text { General } \\
\text { teaching }\end{array}$ \\
\hline School & $\begin{array}{l}\text { Apprentice } \\
\text { centers }\end{array}$ & $\begin{array}{c}\text { Local } \\
\text { vocational }\end{array}$ & \multicolumn{2}{|c|}{ National vocational schools } & High school \\
\hline $\begin{array}{c}\text { Future } \\
\text { engineers or } \\
\text { teachers }\end{array}$ & & & & $\begin{array}{c}\text { Technical } \\
\text { high } \\
\text { school } \\
\text { diploma }\end{array}$ & \\
\hline $\begin{array}{l}\text { Future } \\
\text { technicians }\end{array}$ & & \multicolumn{2}{|c|}{$\begin{array}{l}\text { Industrial training certificate } \\
\text { Vocational technician } \\
\text { diploma }\end{array}$} & & General way \\
\hline $\begin{array}{l}\text { Future } \\
\text { workmen }\end{array}$ & $\begin{array}{l}\text { Vocational } \\
\text { ability } \\
\text { certificate }\end{array}$ & & & & \\
\hline \multirow[t]{2}{*}{ School } & & & & & $\begin{array}{l}\text { Junior high } \\
\text { school }\end{array}$ \\
\hline & \multicolumn{4}{|c|}{ Primary school } & \\
\hline
\end{tabular}

Matrix 1. In 1952, the new structure of technical education (in bold, the changes)

\begin{tabular}{|c|c|c|c|c|}
\hline Organization & \multicolumn{3}{|c|}{ Technical teaching } & General \\
\hline School & $\begin{array}{l}\text { technical } \\
\text { teaching } \\
\text { middle }\end{array}$ & \multicolumn{2}{|c|}{ Technical high schools } & High school \\
\hline $\begin{array}{c}\text { Future } \\
\text { engineers or } \\
\text { teachers }\end{array}$ & & & $\begin{array}{l}\text { Technical high } \\
\text { school diploma }\end{array}$ & \multirow{3}{*}{ General way } \\
\hline $\begin{array}{c}\text { Future } \\
\text { technicians }\end{array}$ & & $\begin{array}{c}\text { Vocational technician } \\
\text { diploma } \\
\text { Technician high } \\
\text { school diploma }\end{array}$ & & \\
\hline $\begin{array}{c}\text { Future } \\
\text { workmen }\end{array}$ & $\begin{array}{c}\text { Vocational } \\
\text { ability } \\
\text { certificate } \\
\text { vocational } \\
\text { study diploma }\end{array}$ & & & \\
\hline \multirow[t]{2}{*}{ School } & & & & $\begin{array}{c}\text { Junior high } \\
\text { school }\end{array}$ \\
\hline & \multicolumn{4}{|c|}{ Primary school } \\
\hline
\end{tabular}

Matrix 2. In 1969, after the democratization (in bold, the change)

\subsection{The 60's, The Adaptation to the Modernity and to One Unified Educational System}

In the early 1960's, compulsory school age becomes 16 . Two facts influence the evolution of the educational system: (i) the democratization of education and its mass dissemination; (ii) a shortage of skilled technicians.

Therefore, technical education is again involved and its degrees are restructured. The first one of the "apprentice centers" becomes "technical middle school". At the second one, the "local vocational schools" and the "national vocational schools" are merged into new "technical high schools" progressively integrated in the unified school system.

Technical teachers are better trained in specialized areas. New teachers are trained in different areas (mechanics, industrial electricity, biochemistry...). The administrative status of these theoretical technical teachers (drawing, technology of mechanical manufacturing...) is aligned on the status of the teachers of general-high schools (1959). For the practical technical teachers, two years of pedagogical training are implemented with an official certificate of teaching (1965). From 1961, in the same way, the teachers (mainly females) of arts and crafts and home economics have the same certificates. In 1962, due to new requirements in the areas of health and nutrition, home economics becomes more scientific mainly in physiology and biochemistry. The high-level competitive examination for the recruitment of teachers, "Agrégation" in French, is created to select the teachers' trainers and the inspectors. In 1968, the same movement concerns mechanics.

Finally, under the influence of Lucien Géminard (Arts et Métiers engineer and general inspector of technical education), each of the three most scientific "industrial training certificates" (mechanics, electro-mechanics, electronics) is converted into a "technician high school diploma" (first examination in 1969). Its programs include the technical analysis of artifacts and their functional schema. These new contents reveal a more scientific and technological approach of technical teaching, in comparison with the "machines paradigm". In the upper high school and university, the technical teaching is born with the creation of the "superior technician diploma" in 1962 and a 
"technological university diploma" in 1966.

At the same time, the different general junior high schools are harmonized without affecting the "apprentice centers". Their label changes to "technical teaching middle school", but their aims - the vocational training - do not change. In 1966, a new workman-training diploma the "vocational study diploma" is established, more generalist than the "vocational ability certificate" (Matrix 2).

These changes show the great evolution: the separation between the vocational training and the technological education, confirmed by two successive reforms.

\subsection{The Two Reforms of the 70's, the Separation between the Vocational Training and the Technological Studies}

Two important reforms affect the school system in the 70's and achieve its unification. The first one (law: 1971) is the introduction of technological teaching. This change officially distinguishes the vocational schools and the technological schools. The second reform is known by the name of its initiator, the minister René Haby. In 1975, he creates a unique junior high school which postpones the beginning of the vocational and the technological studies after 15 years' old. The new school-subject "manual and technical education" replaces "manual work". One year later, a decree renamed the "technical teaching middle school" in "vocational teaching high school" (Matrix 3). After this great change, three different high schools exist: vocational, technological and general studies. So distinguished from vocational training, technological education keeps on its evolution. In 1975, three new "Agrégations" of mechanical engineering, electrical engineering and civil engineering are instituted. Two years later, some technological "classes préparatoires aux grandes écoles" are open. In these high school classrooms, a new paradigm is implemented for the analysis of automatized systems. An artefact is considered as a "black box" with energy, matter and information inputs and outputs. In the same time, home economics has been declining for the benefit to the nutritional sciences and the medical and social sciences.

Thus, the school system evolution upsets the technical teaching.

\subsection{The Reform of the 80's, the Birth of the Technology Education}

The 80 's are a new period for the French school system that begins by a political change. The main aim is defined: an increase of percentage of pupils with a diploma level (baccalauréat) from $40 \%$ to $80 \%$ in 2000 . This aim induces an important upset in the vocational training and the technological teaching, their organization, diploma and contents.

In 1985, with a new law, the names of the high school changes again: the "vocational teaching high school" becomes the "vocational high school", and the "technical high school" becomes the "technological high school". On one hand, the specific purposes of these two courses are accentuated with the creation of the vocational high school diploma (baccalauréat professionnel). On the other hand, the "technician high school diploma" becomes a technological high school diploma (baccalauréat technologique), more generalist (Matrix 4). In this sense, in 1986, a joint propaedeutic training year was created for this two diploma, named the "automatics system technology". Then, the new automatics system paradigm, unifies different technological school-subjects (mechanics, electronics, energetics, pneumatics...). In continuation, two years later (1988), the manual work on mechanical-tools is moved by information technology. The practical teachers then are joined with theoretical teachers with a new certification in mechanical, electrical or civil engineering. In the same time, the changes affect the junior high school with the generalization of "technology education" instead of "manual and technical education" [7]. The "technology education", without not any vocational aim, is for the whole of pupils. A new certification of technology teachers for junior high schools is created (1985). At the same period, in the university, mechanical and electrical engineering courses appear.

\begin{tabular}{|c|c|c|c|c|}
\hline Organization & Vocational teaching & \multicolumn{2}{|c|}{ Technological teaching } & $\begin{array}{l}\text { General } \\
\text { teaching }\end{array}$ \\
\hline School & $\begin{array}{l}\text { vocational teaching } \\
\text { high schools }\end{array}$ & \multicolumn{2}{|c|}{ Technical high schools } & High school \\
\hline $\begin{array}{c}\text { Future engineer } \\
\text { or teacher }\end{array}$ & & & $\begin{array}{l}\text { Technical high } \\
\text { school diploma }\end{array}$ & \multirow{3}{*}{$\begin{array}{c}\text { General way } \\
\text { without } \\
\text { technology }\end{array}$} \\
\hline $\begin{array}{c}\text { Future } \\
\text { technician }\end{array}$ & & $\begin{array}{c}\text { Technician } \\
\text { high schools }\end{array}$ & & \\
\hline $\begin{array}{l}\text { Future } \\
\text { workman }\end{array}$ & $\begin{array}{l}\text { Vocational ability } \\
\text { certificate } \\
\text { Vocational study } \\
\text { diploma }\end{array}$ & & & \\
\hline \multirow{2}{*}{ School } & \multicolumn{4}{|c|}{ Junior high school } \\
\hline & \multicolumn{4}{|c|}{ Primary school } \\
\hline
\end{tabular}

Matrix 3. After the 70's reforms (in bold, the change) 


\begin{tabular}{|c|c|c|c|}
\hline Organization & $\begin{array}{c}\text { Vocational teaching } \\
\text { School }\end{array}$ & $\begin{array}{c}\text { vocational high } \\
\text { school }\end{array}$ & \multicolumn{2}{|c|}{ Technological teaching } & $\begin{array}{c}\text { General } \\
\text { teaching }\end{array}$ \\
\hline $\begin{array}{c}\text { Future engineer } \\
\text { or teacher }\end{array}$ & $\begin{array}{c}\text { Technical high } \\
\text { Future } \\
\text { technician }\end{array}$ & $\begin{array}{c}\text { Technologic } \\
\text { high school } \\
\text { diploma }\end{array}$ & High school diploma \\
\hline \multirow{2}{*}{$\begin{array}{c}\text { Future } \\
\text { workman }\end{array}$} & $\begin{array}{c}\text { Vocational ability } \\
\text { certificate } \\
\text { Vocational study } \\
\text { diploma } \\
\text { Vocational high } \\
\text { school diploma }\end{array}$ & \multicolumn{2}{|c|}{$\begin{array}{c}\text { General way } \\
\text { without } \\
\text { technology }\end{array}$} \\
\cline { 1 - 3 } School & \multicolumn{2}{|c|}{ Junior high school } & \\
\cline { 2 - 3 } & \multicolumn{2}{|c|}{ Primary school } \\
\hline
\end{tabular}

Matrix 4. After the 80's reform (in bold, the change)

\begin{tabular}{|c|c|c|c|c|}
\hline Organization & Vocational way & Technological way & \multicolumn{2}{|c|}{ General way } \\
\hline School & $\begin{array}{c}\text { Vocational high } \\
\text { school }\end{array}$ & \multicolumn{2}{|c|}{ General and technologic high school } \\
\hline $\begin{array}{c}\text { Future engineer } \\
\text { or teacher }\end{array}$ & & $\begin{array}{c}\text { Scientific high } \\
\text { school } \\
\text { diploma (with } \\
\text { options) }\end{array}$ & \\
\hline $\begin{array}{c}\text { Future } \\
\text { technician }\end{array}$ & $\begin{array}{c}\text { Sciences and } \\
\text { industrial } \\
\text { technologies high } \\
\text { school diploma }\end{array}$ & \multirow{2}{*}{$\begin{array}{c}\text { General way } \\
\text { without } \\
\text { technology }\end{array}$} \\
\hline $\begin{array}{c}\text { Future } \\
\text { workman }\end{array}$ & $\begin{array}{c}\text { Vocational } \\
\text { ability certificate } \\
\text { Vocational high } \\
\text { school diploma }\end{array}$ & \multicolumn{3}{|c|}{} \\
\hline School & \multicolumn{3}{|c|}{ Junior high school } \\
\cline { 2 - 4 }
\end{tabular}

Matrix 5. The three ways of educational system (in bold, the change *with industrial technology option in 1992 and engineering sciences option in 2000)

At all of these degrees, the technological contents change with the systemic analysis and practical work on real technological systems. The new vision of the technology is now clearly oriented to the functional analysis and the conception rather than the production.

\subsection{The Turning Point of the $20^{\text {th }}$ Century, the Triumph of Engineering Sciences}

The turn of the $20^{\text {th }}$ century is a new occasion for some positive evolutions of technological teaching.

In 1992, the renovation of the high schools formalizes the three ways, vocational, technological and general, whose foundations date from Liberation. If the "vocational high school diploma" does not move, the "technological high school diploma" is qualified such as the "sciences and industrial technologies" whereas the "technical high school diploma" obtains the more prestigious designation of "scientific high school diploma" with an "industrial technology option". This diploma is now propaedeutic to the new "engineering industrial sciences", a school-subject within the "classes préparatoires aux grandes écoles" (1995). At the beginning of the 2000's the "industrial technology option" of the "scientific high school diploma" is renamed to "engineering sciences option" (Matrix 5). This evolution to an excellence way appears such as a consecration for a school-subject devalued for a long time. At this moment, the engineering sciences develop the "system-analysis paradigm" and the three dimensions (3D) modelling aided by computer. In 2008, under the influence of the general inspection, the syllabuses of technology education within junior high schools are redesigned [8]. With the "pluri-technical system paradigm", the new contents prefigure a harmonization between high schools and "classes préparatoires aux grandes écoles". In the vocational way, the "vocational study diploma" disappears (2009).

However, this changes do not affect the new "sciences and industrial technologies" whose programs have not veritably revised since 1988. It's a new challenge for the technological teaching.

\subsection{The Break of 2010}

As in 1946, and in 1959 for technical teaching and in 1985 for vocational teaching, technological teaching is involved within the school system in order to enable school system to elevate its level in France, i.e., to be in conformity with the aims of Lisbon: 50\% same age-group with baccalaureate level. 


\begin{tabular}{|c|c|c|c|c|}
\hline Organization & Vocational way & Technological way & \multicolumn{2}{|c|}{ General way } \\
\hline School & $\begin{array}{c}\text { Vocational high } \\
\text { school }\end{array}$ & \multicolumn{2}{|c|}{ General and technologic high school } \\
\hline $\begin{array}{c}\text { Future engineer } \\
\text { or teacher }\end{array}$ & $\begin{array}{c}\text { Sciences and } \\
\text { technologies of } \\
\text { industries and } \\
\text { high school } \\
\text { diploma }\end{array}$ & $\begin{array}{c}\text { Scientific high } \\
\text { school diploma } \\
\text { (engineering } \\
\text { sciences } \\
\text { option) }\end{array}$ & $\begin{array}{c}\text { General } \\
\text { way } \\
\text { without } \\
\text { technology }\end{array}$ \\
\hline $\begin{array}{c}\text { Future } \\
\text { workman }\end{array}$ & $\begin{array}{c}\text { Vocational ability } \\
\text { certificate } \\
\text { Vocational high } \\
\text { school diploma }\end{array}$ & \multicolumn{3}{|c|}{} \\
\hline School & \multicolumn{3}{|c|}{ Junior high school } \\
\cline { 2 - 4 }
\end{tabular}

Matrix 6. The contemporary situation (in bold, the change)

Thus, in 2010, the technological high school diploma (baccalauréat technologique) is completely updated. The scientific general teaching replaces the applied-sciences. It is exactly a deprofessionalization and a despecialization of this training. As the engineering high school diploma, the aim is to keep on studying to tertiary school, in particular "classes préparatoires aux grandes écoles" and "engineer schools". The technological contents are structured around matter, energy and information. This important reform allows opportunities to take account of the sustainable development. The different specialties (mechanics, electronics, energetics...) are merged in different options and a common teaching that uses the engineering method with Systems Modelling Language (SysML) imported from informatics. The technician education is currently reported in tertiary school (Matrix 6). This revolution continues with the teachers' certification: the specialties of mechanics, electronics, energy... are merged into the undifferentiated engineering with the label "engineer industrial sciences teaching".

Thus, a technology curriculum from the junior high school (and primary school) to the tertiary school is built with the same teachers and progressive contents. After the secondary school, the technological course or the engineering open the doors for tertiary school.

\section{Conclusions}

In 1945, technology is not a school-subject but only one of the three vocational school-subjects with manual work on mechanical-tools and technical drawing. The engineering sciences do not exist. The disciplinarization-process of technology is the product of vocational technical teaching moving towards a general teaching of engineering sciences, i.e. the transition from an utilitarian vocational objectives-driven to an academic subject-based content-driven [9]. This lengthy process results in three main linked changes: political, institutional and contents in relationships with technical environment.

According to the historical periods and the evolution of society, the assignment for technology education within high school successively are the rebuilding of the country and the increasing of the workforce that needs higher and higher qualifications and consequently longer schooling. The political and socio-economics choices are translated in a progressive aligning of the different school ways to the general secondary school model (same recruitment of teachers, extension of the school career, rejection of workshops...). This trend drives the deprofessionalization and the despecialization of technology at school with important effects on the contents. These contents are in a constant progress. Under the influence of innovative teachers and inspectors, industrial technology and teaching methods vary in different paradigms. Currently, the purposes and the actualization of contents are fundamental in order to justify and to legitimate their existence, such as it has been shown with the disappearing of home economics.

Thus, for 70 years, one part of the vocational technical teaching has been becoming an academic subject. On one hand, the relegation of the vocational education way keeps on existing. The two high school diploma of technology and engineering are more similar. Technology education and engineering currently are one of the better ways to rise to "engineer schools" or universities: $80 \%$ of students titular of "engineer sciences high school diploma" keep on studying in "classes préparatoires aux grandes écoles".

If evolution keeps on the same trend, with simplification of school system and its alignment on the European model, the technological way could disappear (Matrix 7). 


\begin{tabular}{|c|c|c|c|}
\hline Organization & $\begin{array}{c}\text { Vocational } \\
\text { way }\end{array}$ & \multicolumn{2}{|l|}{ General way } \\
\hline School & $\begin{array}{l}\text { Vocational } \\
\text { high school }\end{array}$ & \multicolumn{2}{|l|}{ General high school } \\
\hline $\begin{array}{l}\text { Future engineer } \\
\text { or teacher } \\
\text { diploma }\end{array}$ & & $\begin{array}{c}\text { Scientific high school diploma } \\
\text { (engineering sciences and technology } \\
\text { option) }\end{array}$ & \multirow[b]{2}{*}{$\begin{array}{l}\text { General way } \\
\text { without } \\
\text { technology }\end{array}$} \\
\hline $\begin{array}{l}\text { Workman } \\
\text { diploma }\end{array}$ & $\begin{array}{c}\text { Vocational } \\
\text { ability } \\
\text { certificate } \\
\text { Vocational } \\
\text { high school } \\
\text { diploma }\end{array}$ & & \\
\hline \multirow{2}{*}{ School } & \multicolumn{3}{|c|}{ Junior high school } \\
\hline & \multicolumn{3}{|c|}{ Primary school } \\
\hline
\end{tabular}

Matrix 7. The future situation? (in bold, the possible change)

[5] Hamon, C. Le baccalauréat technique. De la technologie industrielle aux sciences de l'ingénieur [The Technical high school Diploma. From Industrial Technology to Engineering Sciences], 1944-2014. Presses Universitaires de Rennes, Rennes, 2015.

\section{REFERENCES}

[1] A shorter version of this paper has been published in Proceedings of PATT 29 Conference on Plurality and Complementarity of Approaches in Design and Technology Education. Taken from the internet on June 8, 2015 from the URL:

https://hal.archives-ouvertes.fr/hal-01161553/file/PATT29.p df

[6] Lebeaume, J. L'enseignement ménager en France 1880-1980. Sciences et Techniques au féminin, [Home Economics in France 1880-1980. Science and Technics for Women], Presses universitaires de Rennes, Rennes, 2014.

[7] Lebeaume, J. Between Technology Education and Science Education: a Necessary Positionning. In M. J. de Vries (Ed.) Positioning Technology Education in the Curriculum, 75-86, Sense Publishers, Rotterdam, 2011.

[2] Goodson, I. Becoming an academic subject, British Journal of Sociology of Education, Vol. 2, n² 2, 163-180, 1981.

[3] de Vries, M.-J. Positioning Technology Education in the Curriculum, Sense Publishers, Rotterdam, 2011.

[4] Lebeaume, J. (2004). Designing Technology Education at the Junior High School Level: Propositions from the French School Curriculum. The Journal of Technology Studies. Vol. XXX, 3, 2-9.

[8] Lebeaume, J. Integration of Science, Technology, Engineering and Mathematics: Is the Curricular Revolution really possible in France? Design and Technology Education, An International Journal, Vol. 16, n 1, 47-52, 2011.

[9] Ross, A. Curriculum. Construction and critique, Rouledge Falmer, London, 2000. 